\title{
頸動脈小体腫瘍摘出術での内頸動脈の処理
}

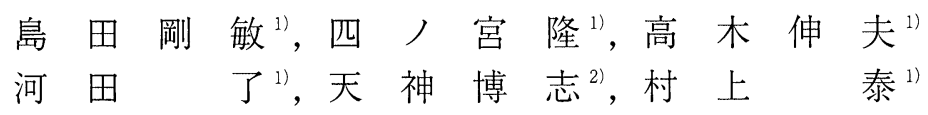

\begin{abstract}
要旨 頸動脈小体腫瘍摘出術時の内頸動脈処理について検討した 2 症例について報告した。いずれ も術前に balloon occlusion test を施行し, 内頸動脈は結紮可能と判断していた。症例 1 では内頸 動脈の中外膜間に血腫を生じたが特に処置を加えず，術後問題を生じなかった。症例 2 では内頸動 脈に一部裂傷を生じその上下をクランプしつつ縫合したが，術後右後頭葉に梗塞を生じ，めまい感 と左上 $1 / 4$ 半盲が出現した。クランプによる内膜剥離あるいは縫合部の血栓遊離による梗塞，ま たは右後大脳動脈の血流低下が考えられた。反省点として，1）抗凝固剤投与の必要性，2）血栓 の wash-out，3）内頸動脈結紫，4）術前脳血管造影などによるさらに詳細な検討，の必要性が 挙げられこれらについて考察した。

キーワード：頸動脈小体腫瘍, 内頸動脈結紮, 脳梗塞, アンギオ下動脈血流遮断試験（balloon occlusion test)
\end{abstract}

\section{Summary Treatment of ICA in the extirpation of carotid body tumor :}

Taketosi Shimada ${ }^{1)}$, Takashi Shinomiya ${ }^{1)}$, Nobuo Takadi ${ }^{1)}$, Ryo Kawata ${ }^{1)}$ Hiroshi Tenjin ${ }^{2)}$ and Yasushi Murakami ${ }^{11}$

${ }^{1)}$ Department of Otolarygology, Kyoto Prefectural University of University of Medicine, Kyoto

${ }^{2)}$ Department of Neurosurgery, Kyoto Prefectural University of University of Medicine, Kyoto

Treating patients with carotid body tumor occasionally requires permanent occlusion of the internal carotid artery. In this paper, we report two cases with some problems in dealing with the internal carotid artery in the operation.

To determine the indication of ligation of internal carotid artery (ICA), we usually try balloon occlusion test and measure stump pressure and cerebral blood flow $(\mathrm{CBF})$ with studying EEG, neurological findings, and collateral circuration.

One case was a 53-year-old woman. We could extirpate the carotid body tumor in the subadventitial plane. After the extirpation we found subadventitial-hematoma-like change. It did not increase in size and we left it. She had no problem after the operation.

The other case was a 41-year-old man. When we were resecting the carotid body tumor, the wall of ICA was lacerated. We sutured the wall by $7-0$ nylon. 48hours after the operation, he complained upper left quadrantic hemianopsia. We studied brain CT and found brain infarction in right posterior lobe. We could not determine it was because of thrombosis of posterior cerebral artery from the suture of ICA or decrease of blood flow.

We think 1) wash-out of thrombus before finishing the suture of ICA and 2) heparinization during and after the operation 3) ligation of ICA and 4) more detailed examination of preoperative angiography and etc. are necessary.

Key words : Carotid Body Tumor, Ligation of ICA, Brain Infarction, Balloon Occulusion Test

\footnotetext{
*1) 京都府立医科大学耳鼻咽唤科学教室

*2) 京都府立医科大学脳神経外科学教室
} 


\section{はじめに}

頸動脈小体腫瘍は頸動脈分岐部に存在する化学 受容体である頸動脈小体に発生する paraganglioma で, その治療は外科的切除が一般的であ る。摘出術時の内頸動脈に対する操作は厳重な注 意を要し,術前のアンギオ下血流遮断試験(balloon ovvlusion test）は内頸動脈結紮適否の基準として の必須の検査となっている。

今回我々は腫瘍摘出術時に内頸動脈に異常所見 を認めた 2 症例を経験し，その処理について検討 を加えたので報告する。

\section{症例 1}

患者：53歳，女性

主訴：左無痛性頸部腫瘤

家族歴，既往例：特記すべきものなし

現病歴：1993年 8 月 左頸部腫瘤に気付いてい たが，無痛性でほかの合併症状がないため放置し ていた。その後腫瘤が徐々に増大してくるため, 1993年10月他院耳鼻科を受診し，頸動脈小体腫瘍 の疑いにて1993年10月20日当科を紹介されて受診 した。

現症：左上頸部に径 $5 \times 5 \mathrm{~cm}$ ，表面平滑，境 界明瞭，弾性軟，左右に可動性良好，上下に可動 性不良の腫瘤を触知した。神経脱落症状は認めな かった。

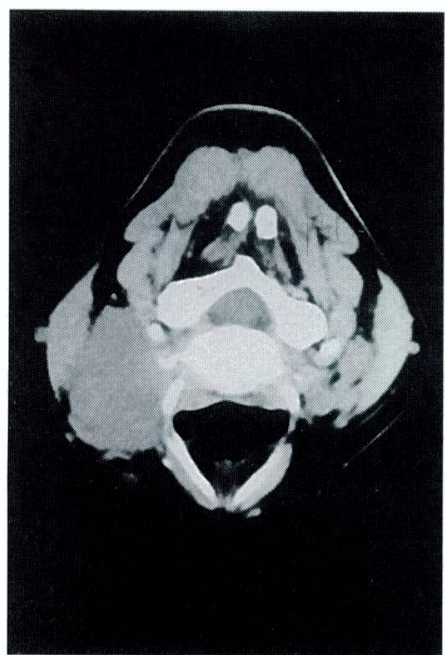

図 1 (単純 CT) 左頸動脈分岐部に占拠性病変を認 める。

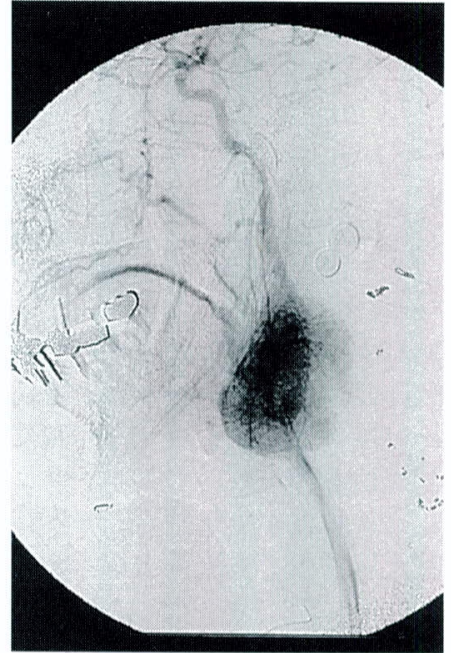

図 2 (左頸動脈造影) 頸動脈分岐部に腫瘍濃染像を 認める。外頸動脈，内頸動脈は前後に圧排されている。

検査成績：血中，尿中カテコラミンは正常值範 囲内であった。

頸部 CT 所見：単純 CT にて左頸動脈分岐部 に占拠性病変を認めた（図 1 ）。

頸動脈造影所見：左頸動脈造影で，頸動脈分岐 部に外頸動脈を栄養血管とする腫漡濃像を認め, 外頸動脈，内頸動脈は前後に圧排されていた。動 脈壁の不整像は認めなかった（図 2 )。

balloon occlusion test：総頸動脈, 内頸動脈合 併切除，結紮に備え施行した balloon occlusion test で, 脳主幹動脈断端圧（stump pressure）で は閉塞前後で $90 \rightarrow 68 \mathrm{mmHg}$ と閉塞前の76\%保た れていた。前, 後交通動脈を介しての対側からの 充分な cross flow が確認され，脳波に変化なく， 神経症状も特に認めなかった。transcranial Doppler （TCD）による中大脳動脈血流速度も変化は認め なかった。

以上より，やむを得ない場合は総頸動脈，内頸 動脈は結紮可能と判断し，1993年11月22日全身麻 酔下に摘出術を施行した。

手術所見：頸部横皮切, 胸鎖乳突筋前縁より腫 瘍に到達した。内頸静脈は結紮切断した。腫瘍上 方に舌下神経を確認し保存した。腫瘍は外頸動脈 と内頸動脈の間に挟まれて存在していた。まず外 頸動脈を腫痬下端で結紮切断し, これにより出血 が減少した。中外膜間剥離法にて内頸動脈より腫 瘍は比較的容易に剥離出来た。腫瘍上端にて再び 


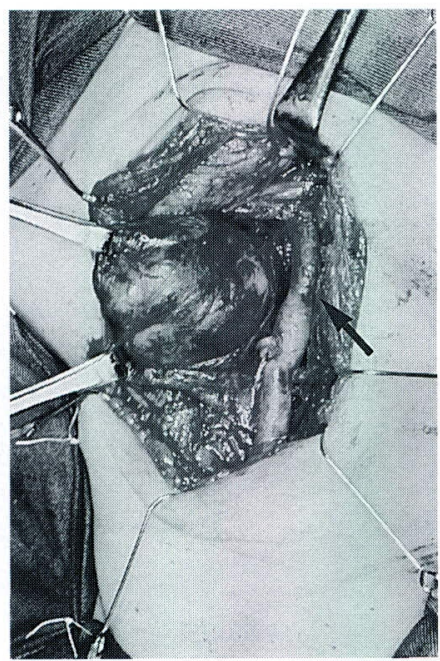

図 3 (手術所見) 腫瘍摘出直後の内頸動脈中外膜間 に，少量出血したと思われる血腫様変化を認好（矢 印)。数分間の観察で，進行を認めなかった。

外頸動脈を結紮切断し腫瘍を摘出した。迷走神経 は確認保存した。出血量は $373 \mathrm{ml}$ であった。

摘出後，腫瘍摘出部より頭側で内頸動脈の中外 膜間に少量出血したと思われる。血腫様所見を認 めたが，数分観察し進行する様子がないため追加 処置を行わずに閉創した（図 3 )。

病理所見：paraganlioma

術後経過：神経学的に特に異常を生じなかった。 経過順調にて術後20日目に退院した。

\section{症例 2}

患者：41歳，弾性

主訴：無痛性頸部腫瘤

現病歴：1985年より右頸部腫瘤に気付いていた が，他に症状がないために放置していた。1994年 8 月他院を受診し，頸動脈小体腫瘍疑いにて1994 年11月 9 日当科を紹介されて受診した。

現症：右頸部に径 $4.5 \times 4.5 \mathrm{~cm}$ ，表面平滑，境 界明瞭，弾性硬，左右に可動性良好，上下に可動 性不良の腫瘤を触知した。神経脱落症状は認めな かった。

検査成績：血中，尿中カテコラミンは正常值範 囲内であった。

頸部 CT 所見：右頸動脈分岐部に強く造影さ れる占拠性病変を認めた（図 4 )。

頸動脈造影所見：右頸動脈造影で，頸動脈分岐

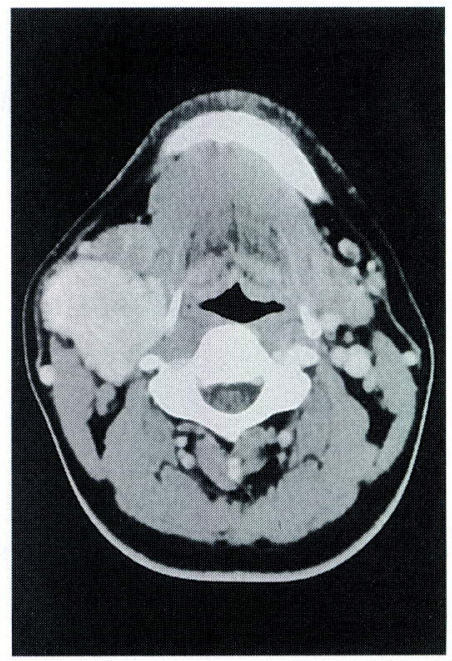

図4（造影 CT）右頸動脈分岐部に強く造影される 占拠性病変を認める。

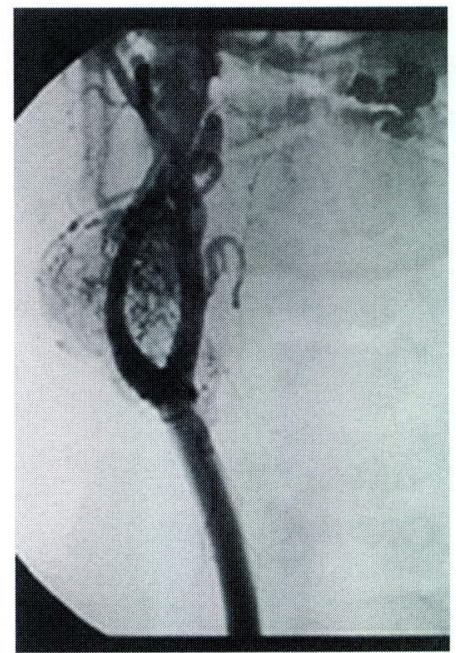

図 5 (右頸動脈造影) 䁰動脈分岐部に外頚動脈の分 岐を栄養血管とする腫瘍濃染像を認める。外頸動脈, 内頸動脈は前後に圧排されている。

部に外頸動脈の分枝を栄養血管とする腫瘍濃染像 を認めた。外頸動脈，内頸動脈は前後に圧排され ていた。動脈壁の不整像は認めなかった（図５）。 balloon ovvlusion test: 総頸動脈, 内頸動脈合 併切除, 結紮に備えて施行した balloon occlusion test で, stump pressure は閉塞の前後で95 $\rightarrow 77$ $\mathrm{mmHg}$ と閉塞前の77\%保たれていた。前交通動 脈を介しての対側からの充分な cross flow が確 認された。後大脳動脈は頸動脈系から還流されて いた。脳波に変化なく, 神経症状も特に認めな 
かった。TCDによる中大脳動脈血流速度は閉塞 前の $89 \%$ 保たれている。

以上より, やむを得ない場合は総頸動脈, 内頸 動脈は結紫可能と判断し，1995年 2 月 8 日全身麻 酔下に摘出術を施行した。

手術所見: 頸部横皮切, 胸鎖乳突筋縁より腫瘍 に達した。内頸静脈は結紮, 切離し腫瘍より剥離 した。腫瘍と総頸動脈を中外膜間剥離法にて剥離 する際，出血が多かったため総頸動脈をブルドッ ク鉗子にてクランプし, 外頸動脈を結紮, 切離し デクランプした。上方に剥離を進め, 腫瘍と内頸 動脈を剥離する際，一部内頸動脈壁に裂傷を生じ, 裂傷の上下で内頸動脈をクランプし， 7-0ナイ ロン糸にて 5 針縫合した後，デクランプした。術 中抗凝固剤の投与は行わなかった。舌下神経, 迷 走神経は確認, 保存した。術中出血量は $417 \mathrm{ml}$ であった(図 6 )。

病理所見： paraganglioma

術後経過: 術後, 覚醒時より頭痛を訴えていた が神経学的以上を認めなかったため, 鎮痛剤を投 与し経過観察を行っていた。抗凝固剤は投与しな かった。

術後48時間目に視野狭窄を訴え, 緊急頭部 CT にて右後頭葉及び右大脳基底核に梗塞を認めたた め, 以後, 循環改善剤, 抗凝固剤, 高浸透圧利尿 剤の点滴静注を行った。しかしほぼ完成された梗

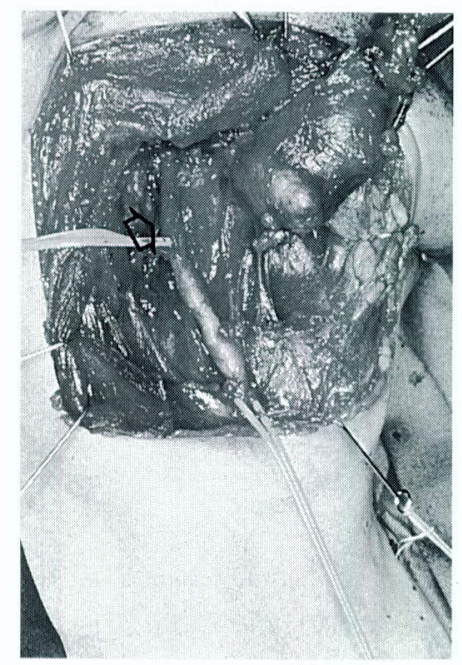

図 6 (手術所見) 腫瘍摘出直後の状態を示す。腫瘍 と内頸動脈を剥離する際, 一部内頸動脈下部に裂傷を 生じ，7ー0ナイロン系で 5 針縫合した（矢印）。

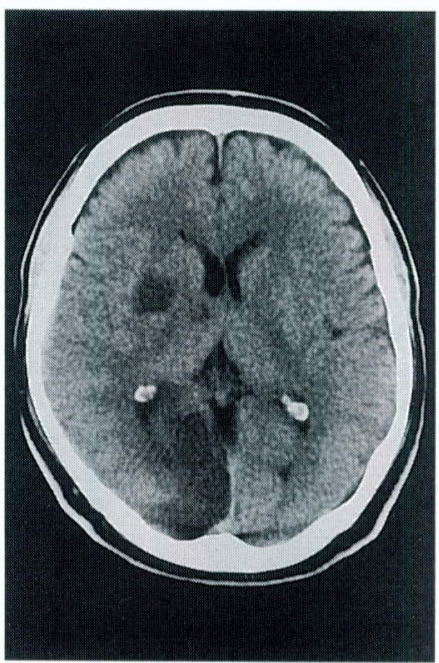

図7 (頭部造影 CT) 術後48時間目で右後頭葉及び 右大の基底核に梗塞を認める。

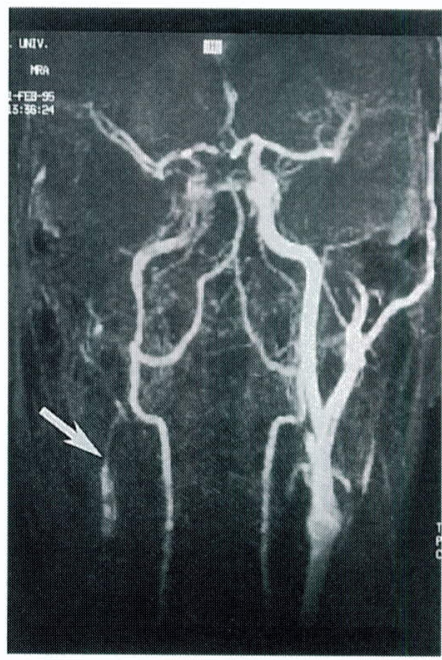

図 8 (MR angiographt) 術後13日目で, 右総頸動脈 より抹消の描出がほとんど認められない。側副血行に より右側の脳血管はよく描出されている。

塞であったため, 左上 $1 / 4$ 半盲が続いた（図 7 )。

頭痛は徐々に改善し, 他の神経学的異常は認め なかった。

術後13日目の MR angiograohy で, 右総頸動 脈より抹消の描出がほとんど認められなかったが, 側副血行により右側の脳血管はよく描出された。 内頸動脈縫合部の血栓形成，または狭窄により右 総頸動脈血流低下を来したものと考えられた（図 8 )。 


\section{考 察}

提示した 2 症例のように, 頸動脈小体腫瘍摘出 術時に総頸動脈, 内頸動脈に問題が生じることが 多い。当科に扮いては当院脳外科の協力を得て術 前に angiography 施行と同時に balloon occlusion test を施行し脳主幹断端動脈圧 (stump pressure) を測定，脳血流量 (cerebral blood flow： $\mathrm{CBF}$ ), 側副血行, 神経学的所見, 脳波とあわせ 内頸動脈閉塞試験時のモニターとしている。

また当院では脳血流量の測定時には SPECT (single photon emmision CT) を用いているが, cold Xenon CT も用いられる (表 1)。

内頸動脈結紮適否の指標としては $\mathrm{CBF}$, stump pressure，の変化を用いている。(表 2 ) 即ち, CBF が30〜 40 ml $/ 100 \mathrm{~g} / \mathrm{min}$, 閉塞前の $70 \%$ 以上保たれ ること, stump pressure が50〜 60mmHg, 閉塞前 30\%以上保たれること，を基準としている。

症例 1 において発生した内頸動脈の中外膜間血 腫は術中の観察にて進行する傾向がないために放 置し, 術後特に問題を生じなかったが, 血腫が増 大すれば, 内頸動脈の内膜剥離, 狭窄, 乱流によ る血栓形成，の危険性が考えられた。balloon occlusion test にて内頸動脈は結紫可能との判断を していたので，問題を生じた場合には内頸動脈結 紮をしてしまった方がよかったとも考えられる。

症例 2 においては 1 ) 総頸動脈をクランプ, 外 頸動脈を結紮，デクランプ，2）内頸動脈壁裂傷,

表 1 内頸動脈閉塞試験時のモニター（天神 1995）

1.膎血流量 (cerebral blood flow:CBF)
2.脳主幹断端動脈圧（stump pressure）
3.脳波、脳血管写上の側副血行、神経症状

脳血流量測定 (天样 1995)

1.SPECT(single photon emmission CT)

2.cold Xenon CT

表 2 内頸動脈結禁適否の判断基準（天神 1995）

1. $\mathrm{CBF} 30 \sim 40 \mathrm{ml} / 100 \mathrm{~g} / \mathrm{min}$. 閉塞前の $70 \%$ 以上が保たれること

2. stump pressure $50 \sim 60 \mathrm{mmHg}$, 閉塞前の $30 \%$ 以上が保たれること
3 ) 内頸動脈クランプ, 裂傷部縫合, デクランプ, という操作手順で剥離困難な腫瘍摘出に対処した。 右後頭葉梗塞の原因として，1）内頸動脈, 総頸 動脈のクランプ，デクランプにより血栓または内 膜が遊離し右後大脳動脈の血栓となった可能性,

2 ) 内頸動脈縫合部に形成された血栓が遊離し右 後大脳動脈の塞栓となった可能性，3）内頸動脈 縫合部が縫合による狭窄，または血栓による狭窄 を来たし右後大脳動脈の血流低下を来した可能性 が考えられる。

右後頭葉に生じた梗塞の原因を特定することは 難しいが，1）内頸動脈に裂傷を生じた段階で内 頸動脈結紮，合併切除を行うべきであった，2） 縫合時, 内頸動脈をクランプした際に生じていた 可能性がある血栓の wash out ができていなかっ た，3）術中術後に抗凝固剂を投与すべきであっ た，と考えられた。

術前評価の反省としては, balloon occlusion test 施行時に SPECT で右後頭葉の血流低下は認めな かったが，より詳細な神経症状の評価が出来たの ではないかという点で上げられる。術前の脳血管 造影では, 前交通動脈を介しての側副血行が充分 に認められたが，Willis 環が完全に発達した type ではなかった。すなわち右後大脳動脈は内頸動脈 より血流の供給を受けていた。balloon occlusion test でも右後大脳動脈は前交通動脈を介して血流 の供給を受けていた。但し視野狭窄をはじめとす る神経症状は検査時には認めなかった。

よって,この症例に扔いて内頸動脈結紮を行い, 塞栓症がなかったとしても右後大脳動脈の血流低 下は免れなかった，とも考えられる。これより反 省点として, stump pressure をはじめとする術前 評価に加え, 詳細な脳血管造影の検討及び SPECT などにより脳血流量の部分的な低下をも検討し， 血流低下を来たしやすい部分の詳細な神経症状の 評価をする必要性が出てきた。

balloon occlusion test における stump pressure, CBF は脳全体の重篤な合併症を予見することに おいて有用であることは西山ら ${ }^{1)}$, 天神ら ${ }^{2)}$, 小 池ら ${ }^{3)}$, も述べている。一方, 永田ら ${ }^{4)}$ は, 内頸 動脈を結紮した場合, 遅発性梗塞の可能性は 5 20\%であると述べている。また Miller ら5)は $\mathrm{CBF} 40 \mathrm{ml} / 100 \mathrm{~g} / \mathrm{min}$, 閉塞前の $75 \%$ 以, stump 
pressure $60 \mathrm{mmHg}$ 以上という基準で総頸動脈ま たは内頸動脈の結紮を行い, その結果 $\mathrm{CBF}$ のみ を基準にすると $28 \%$ の一過性症状，13\%の恒久的 症状を残し，CBF，stump pressure の両方を基準 にすると14\%の一過性症状が発生したと報告して いる。また Willis 環が完全に発達している頻 度は約 $18 \%$ である 6 )。

村上ら 7)の報告によれば，本邦における悪性頸 動脈小体腫演の頻度は約20\%であることより症例 2 が手術の適応外であったとは考えられない。今 回我々が経験した術後合併症は，左上 $1 / 4$ 半盲 であり，その他の重篤な合併症は免れることが出 来た。右後頭葉梗塞の原因を特定することは出来 なかったが，さらに安全に手術を行うために詳細 な術前検査の検討が必要であると思われる。

また当科では実施していないが，頸動脈小体腫 㿇摘出術時に，術中体シャントを用いた方法の報 告8,9)や, 内頸動脈の血行再建を要した症例の報 毕10)もあり, 今後の検討課題となるものと考え ている。

$$
\text { まとめ }
$$

頸動脈小体腫瘳摘出術時に問題のあった 2 症例 の内頸動脈の処理について検討した。

\section{参考文献}

1) 西山彰子, 天神博志, 村上泰, 他：内頸動脈結䅨に 関する術前, 術中評価. 耳睤臨床 $87 ： 1 ； 99-10$ 8, 1994.

2 ) 天神博志，上田聖：脳循袈からみた頸動脈，椎骨動 脈結紮の適否. JOHNS 11(5):一, 1995.

3) 小池修治, 鈴木守, 佐竹純一, 他：頭頸部癌頸動脈 浸潤例に対する，術前アンギオ下内頸動脈遮断試験 (Balloon occlusion test) の有用性について, 頭頸 部腫瘍 20(1) $154-159,1994$.

4 ）永田泉, 菊池晴彦：内頸動脈の結䅨に対する考え方. JOHNS $7: 837-840,1991$.

5 ) Miller JD, Jaward K, Jennet B : Safety of carotid ligation and its in the management of intracranial aneurysms. J Neuro Neurosurg Psychiatry $40: 64-$ 72, 1977.

6 ) Riggs HE, Rupp C: Variation on form of circle of Willis. Arch Neurol 8:8-14, 1963.

7 ）村上泰，水野正浩，市村惠一：悪性頸動脈正体腫瘍 の一例一本邦悪性例の検討一. 耳鼻臨床 $80: 627$ $-636$

8 ）村上匡孝, 松岡秀樹, 後藤達也, 他 : 頸動脈小体腫 瘍の 1 治験例一術中肉シャントの一工夫と頸動脈小 体腫演の組織学的検討一.耳鼻頭頸 63(10)：769 $-776,1991$.

9 ）山田洋一郎，木田亮紀，鴨原俊太郎，他 術中内シャント設置による頸動脈小体腫瘳摘出術, 頭頸部外科 4 (2) $1: 189-193,1994$.

10）渡辺周一, 宇野欽哉, 田村耕三, 他： 頸動脈再建を要した頸動脈小体腫瘍の一例. 耳鼻 41:24-28, 1995. 